\title{
Simulation and optimization of key link of Production logistics in automobile production
}

\author{
Yunrui Wang \\ School of Mechanical Engineering, Xi'an University of Science and Technology, Xi' an, 710054, \\ China \\ 2002wyr@sina.com
}

Keywords: production logistics, key link, witness simulation, optimization

\begin{abstract}
Automobile production logistics would affect output rate directly, it included some processes such as cutting, stamping, welding, painting, assembly, testing. For the main question not to delivery in time in a company of main produce car, by observation and analysis in the scene found the painting process was the key link to overall effectiveness. Painting process logistics started from the material entering paint shop, to pre-treatment, coating, inspection, drying, the staging and so on, applying Witness in modeling and simulation according to the current job situation of each station, the running result revealed that the coating station was the bottleneck because of the station was only one line and sometimes needed to spray a variety of colors, two coating lines were added to solve follow two problems: on the one hand, to solve the reciprocating transport problems caused by coating different colors, on the other hand, the block in production line was improved significantly. The new model simulation showed that the average time of body painting was reduced from 100 to 88.5 minutes. This improvement was used in the enterprise and achieved desire target, the car output monthly would boost.
\end{abstract}

\section{Overview}

Automobile industry has become increasingly prominent in national economic development due to the increasing of demand and production, car manufacturer must control and reduce cost in order to win fierce competition, and the efficiency of automotive production logistics has a very important impact in overall production. Computer simulation technology not only can solve complex problem that mathematical method does not, but also play a significant role in production logistics which mainly for research on production logistics system in practical application of enterprise, and through the use of simulation technology to find the key link in logistics, then raise an appropriate solution to improve the efficiency of resource utilization and logistics. Some scholars have already carried out some work in this regard, Zhang Yingli, Shao Mingxi belong of Nanjing Forestry University, using Petri nets to establish a car factory assembly workshop production logistics model, and simulate production line using Visual Basic language [1]. Anhui University of Li Minghe and Lu Weifeng put forward a Petri net model of material handling system in workshop, the system can show vividly on physical process, and reflect the dynamic characteristic, at the same time use ARENA simulation software in research of the system model simulation [2]. The achievement of Zheng shunshui, that is simulation and optimization technology on production line, acts on logistics and production scheduling simulation, analyses the bottleneck equipment and fault, the production line capacity is assessed, these provide a reliable scientific basis on production line planning and scheduling [3]. Tsinghua University, Dong Jianhua, Xiao Tian yuan and others propose three key problem of automobile assembly line for mass customization, put forward to a simulation environment according to a requirement on automobile assembly line planning [4].

Currently, the company sold car fully but often cannot delivery schedule, the simulation technology used in the company's production logistics will find the key which affect their productivity, then propose appropriate solution. The method can reduce the risk in blind improvement and get the goal of improve productivity. 


\section{Production process analysis}

Automobile production flow shown in Figure 1, generally include the following sections: 1) the whole rolled steel cutting and sorting, trimming; 2) assigned to each punch stamping, pressed into the body of each vehicle kinds, such as the front fender, vehicle side panel; 3) welding and inspection for body parts; 4) welding qualified body into paint shop to complete the painting and staging; 5) assemble in accordance with production plan, final assembly including engine, chassis, body (including driver's cab and carriage) and electrical equipment and other four parts; 6) testing after assembly for discover quality problem and reject defective products.

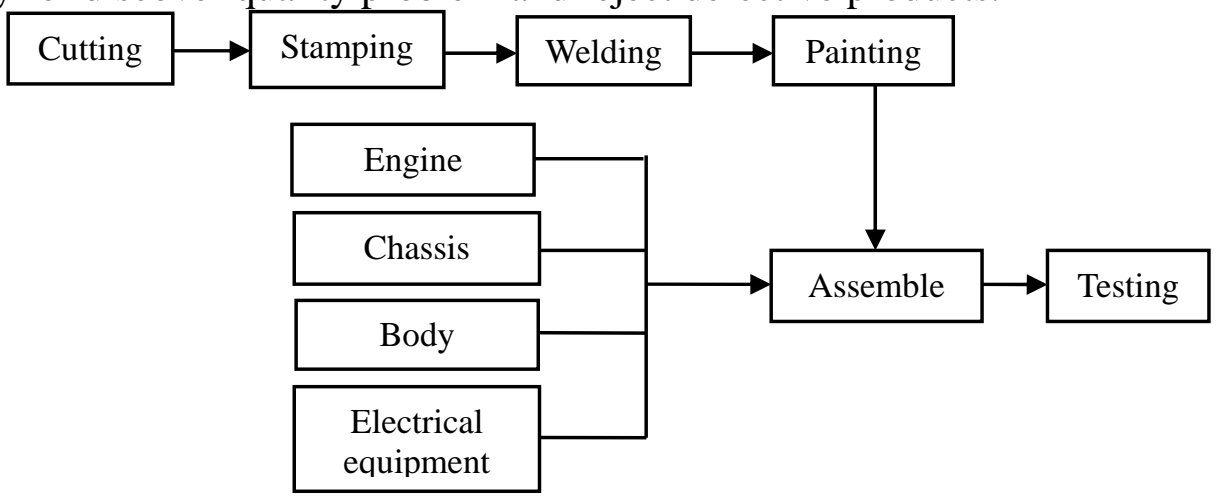

Fig. 1 Automobile production flow chart

An automobile company produce car mainly, assembly line beat currently basically reasonable but often occur downtime due to waiting for some parts, product yield progress in each production line will affect business productivity, finding the painting line is main constraint by observation and analysis on sense. Painting main task is to paint color classification according to the production plan, not only to protect automobile shell, to avoid vehicle body damage, extend the service life , but also as a special logo, different colors and patterns to distinguish different purpose. In addition, reflect the art characteristics of the car and the sense of the times.

Painting as an important part of automobile production, the process can be divided into five steps: pre-treatment, coating, inspection, drying, staging. The aim of Pre-treatment is thoroughly clean and eliminate the body oil, dust and other impurities before the car spraying, reveal the true nature of the object surface so that the body metal can be well combined with paint, in addition to the coated surface may have a certain roughness to prevent blistering, peeling and so on, it includes cleaning, chemical processing, grinding.

\section{Production logistics key link determination}

It can be found that the painting is the key link in production logistics by preliminary observation and analysis. The company has only one coating line but diverse needs of customers require the spraying process continue to transform color, now spraying is going different colors in accordance with the production plan in batch while other color products is waiting, which lead to the spraying equipment use a long time for all the productions, lower synchronism between each station and poor productivity of the coating process, it is often occur another thing that arranging workers who are discontent to work overtime when the order cannot be completed on schedule, further lead the working efficiency. Besides, demanding for the car of different colors to be adjusted will generate unnecessary duplication handling that affect the yield because staging station is in batch according to the production plan, that following apply Witness simulation software to further analyze.

\subsection{Witness Introduction.}

Witness is a powerful simulation software system launched by Lanner that a British company. It can simulate not only for discrete event system but be used in a continuous fluid system. Each component in Witness is called "elements", which provides a large number of model elements describe the industrial system such as machining center, transmitting device, buffer memory apparatus in production line, as well as shift mechanism, time sequence of event, statistical distribution and so on of logic control element, user can easily establish an industrial systems running model using these elements [5]. 


\subsection{Painting process logistics system model establishment.}

Basic link in painting process will mainly be considered while establishing a simulation model in Witness, logistics flow of coating process is shown in figure 2. We can see, material on the procedure enter in painting shop as put-in-storage of this process, following in pre-treatment and then spray the body based on production plan, check the result after spraying complete, qualified production will enter drying and otherwise return repainting, then staging in batch according to production plan after drying for the next assembly process.

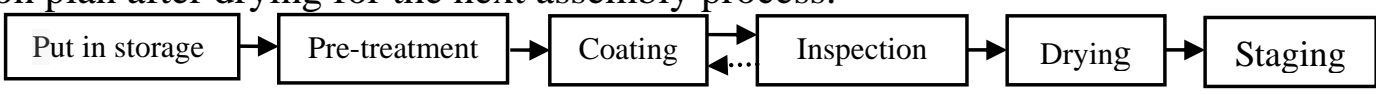

Fig.2 Painting process logistics figure before optimization

There are 4 Machines, five paths and 4 Buffers in Witness simulation modeling according the analysis of the painting process logistics, result shown in Figure 3 [6-7].

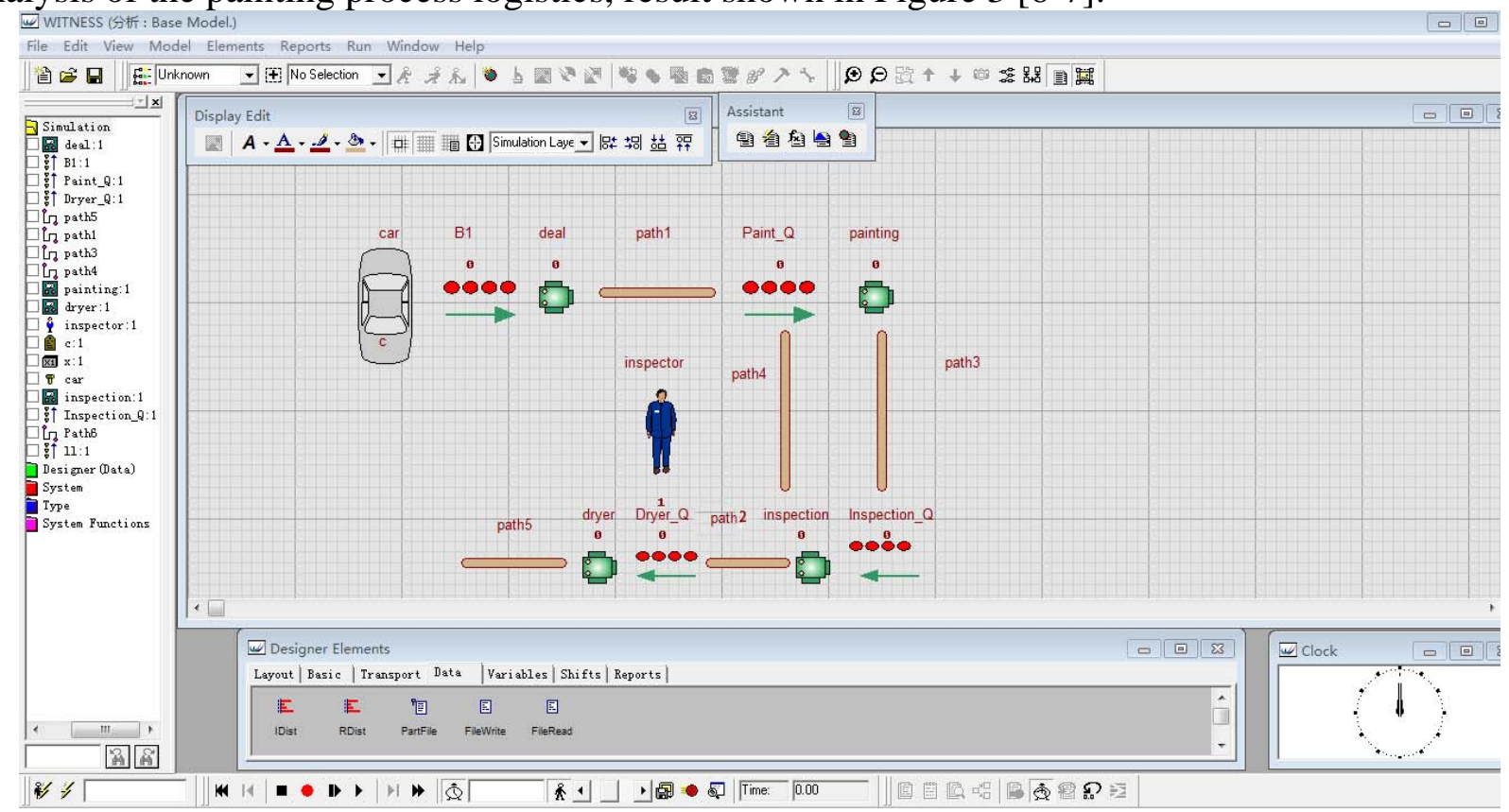

Fig.3 Witness simulation model before optimization

\subsection{Data analysis.}

The simulation results are shown in Figure 4-6 while set 400 min as work time [8-9].

\begin{tabular}{l}
\hline WITNESS \\
Machine Statistics \\
\begin{tabular}{|c|c|c|c|r|r|r|r|r|r|r|r|}
\hline Neport by 0n Shift Time \\
Name & $\begin{array}{c}\% \\
\text { Idle }\end{array}$ & $\begin{array}{c}\% \\
\text { Busy }\end{array}$ & $\begin{array}{c}\% \\
\text { Filling }\end{array}$ & $\begin{array}{c}\% \\
\text { Emptying }\end{array}$ & $\begin{array}{c}\% \\
\text { Blocked }\end{array}$ & $\begin{array}{c}\% \text { Cycle } \\
\text { Wait Labor }\end{array}$ & $\begin{array}{c}\% \\
\text { Setup }\end{array}$ & $\begin{array}{c}\% \text { Setup } \\
\text { Wait Labor }\end{array}$ & $\begin{array}{c}\% \\
\text { Broken }\end{array}$ & $\begin{array}{c}\% \text { Repair } \\
\text { Wait }\end{array}$ & $\begin{array}{c}\text { No. Of } \\
\text { Operation }\end{array}$ \\
\hline deal & 0.00 & 73.50 & 0.00 & 0.00 & 26.50 & 0.00 & 0.00 & 0.00 & 0.00 & 0.00 & 49 \\
\hline painting & 1.50 & 98.50 & 0.00 & 0.00 & 0.00 & 0.00 & 0.00 & 0.00 & 0.00 & 0.00 & 19 \\
\hline dryer & 83.00 & 16.00 & 0.00 & 0.00 & 0.00 & 1.00 & 0.00 & 0.00 & 0.00 & 0.00 & 16 \\
\hline inspection & 65.64 & 18.50 & 0.00 & 0.00 & 9.78 & 6.08 & 0.00 & 0.00 & 0.00 & 0.00 & 18 \\
\hline
\end{tabular}
\end{tabular}

Fig.4 machine working status statistics

Figure 4 is a job data of every process, we can see the machine's idle time is getting longer and longer while busy hour is getting shorter from deal to dryer process, 49 products in deal are completed but painting only 19, a waste of personnel and time occur in dryer and inspection for waiting a long time.

\begin{tabular}{l}
\hline WITNESS \\
Buffer Statistics \\
\begin{tabular}{|c|r|r|r|r|r|r|r|r|c|}
\hline Name & $\begin{array}{c}\text { Total } \\
\text { In }\end{array}$ & $\begin{array}{c}\text { Total } \\
\text { Out }\end{array}$ & $\begin{array}{c}\text { Now } \\
\text { In }\end{array}$ & $\begin{array}{c}\text { Ma } \\
\mathbf{x}\end{array}$ & $\begin{array}{c}\text { Mi } \\
\mathbf{n}\end{array}$ & $\begin{array}{c}\text { Avg } \\
\text { Size }\end{array}$ & $\begin{array}{c}\text { Avg } \\
\text { Time }\end{array}$ & $\begin{array}{c}\text { Avg } \\
\text { Delay }\end{array}$ & $\begin{array}{c}\text { Avg } \\
\text { Delay }\end{array}$ \\
\hline B1 & 101 & 49 & 52 & 52 & 0 & 19.91 & 39.44 & & \\
\hline Paint_Q & 50 & 20 & 30 & 30 & 0 & 19.81 & 79.23 & & \\
\hline Dryer_Q & 16 & 16 & 0 & 1 & 0 & 0.00 & 0.00 & & \\
\hline Inspection & 19 & 19 & 0 & 1 & 0 & 0.06 & 0.68 & & \\
\hline II & 16 & 0 & 16 & 16 & 0 & 7.30 & 91.25 & & \\
\hline
\end{tabular}
\end{tabular}

Fig.5 Buffer working status statistics

Figure 5 shows total amount of buffer is gradually reducing, the average time B1 is $39.44 \mathrm{~min}$ and 
Paint_Q of 79.23min, waiting for inspection and dryer appeared, that spraying work efficiency is lower resulting in waste of time.

\begin{tabular}{l}
\hline \multicolumn{10}{|l|}{ WITNESS } \\
Part Statistics \\
\begin{tabular}{|c|r|r|r|r|r|c|c|c|c|}
\hline Name & $\begin{array}{c}\text { No. } \\
\text { Entered }\end{array}$ & $\begin{array}{c}\text { No. } \\
\text { Shippe }\end{array}$ & $\begin{array}{c}\text { No. } \\
\text { Scrapped }\end{array}$ & $\begin{array}{c}\text { No. } \\
\text { Assemble }\end{array}$ & $\begin{array}{c}\text { No. } \\
\text { Rejected }\end{array}$ & $\begin{array}{l}\text { W.I.P } \\
\text { A }\end{array}$ & $\begin{array}{c}\text { Avg } \\
\text { W.I.P. }\end{array}$ & $\begin{array}{c}\text { Avg } \\
\text { Time }\end{array}$ & Sigma Rating \\
\hline car & 101 & 0 & 0 & 0 & 0 & 101 & 50.50 & 100.00 & 0.00 \\
\hline
\end{tabular}
\end{tabular}

Fig.6 Body working status statistics before optimization

Figure 6 shows the working status of the body, the average working time of each body is 100 minutes when input is 101 units.

\section{Simulation and optimization of key link in production logistics}

The simulation results tell us coating is the key link in painting process namely bottleneck in there. It is necessary to improve production efficiency of spraying because bottleneck waste one hour time equivalent to the entire production line waste one hour. Application software modeling and simulation for a variety of programs, finally determine ideal solution which the coating process of production line add to three different colors in accordance with production plan for divided into color coating, and then pooled together to be checked . It prevents clogging and poor machine utilization problem caused by waiting too long, and reduces waste of duplication handling due to schedule changed while classifies storage in put-out-storage for different colors vehicle body according to the production plan [10], Figure 7 is painting process logistics figure after optimization.

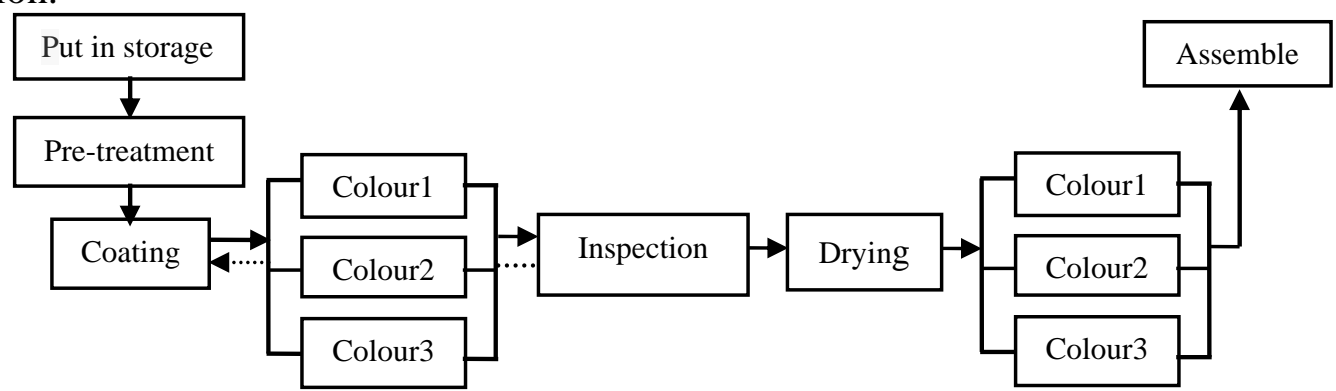

Fig.7 Painting process logistics figure after optimization

\subsection{Building optimization model.}

Vehicle body with different colors spraying classification according to the production plan after optimization, that avoid a long blockage and lower machine productivity due to long spraying time, the product classification storage prevent moving back and forth after drying. Modeling and simultion for this optimization program further define elements as shown in Table 1, Parking procedure is packaging the same color body, then to the buffer, modeling result is shown in Figure 8.

Table 1 Element definition

\begin{tabular}{cccccccc}
\hline S/N & Name & Type & Number & S/N & Name & Type & Number \\
\hline 1 & car & Part & 1 & 10 & Dryer_Q & Buffer & 1 \\
2 & deal & Machine & 1 & 11 & Packing_Q & Buffer & 1 \\
3 & painting & Machine & 3 & 12 & path1 & Path & 1 \\
4 & inspection & Machine & 1 & 13 & path2 & Path & 1 \\
5 & dryer & Machine & 1 & 14 & path3 & Path & 1 \\
6 & packing & Machine & 1 & 15 & path4 & Path & 1 \\
7 & B1 & Buffer & 1 & 16 & path5 & Path & 1 \\
8 & Paint_Q & Buffer & 1 & 17 & path6 & Path & 1 \\
9 & Inspection_Q & Buffer & 1 & & & & \\
\hline
\end{tabular}




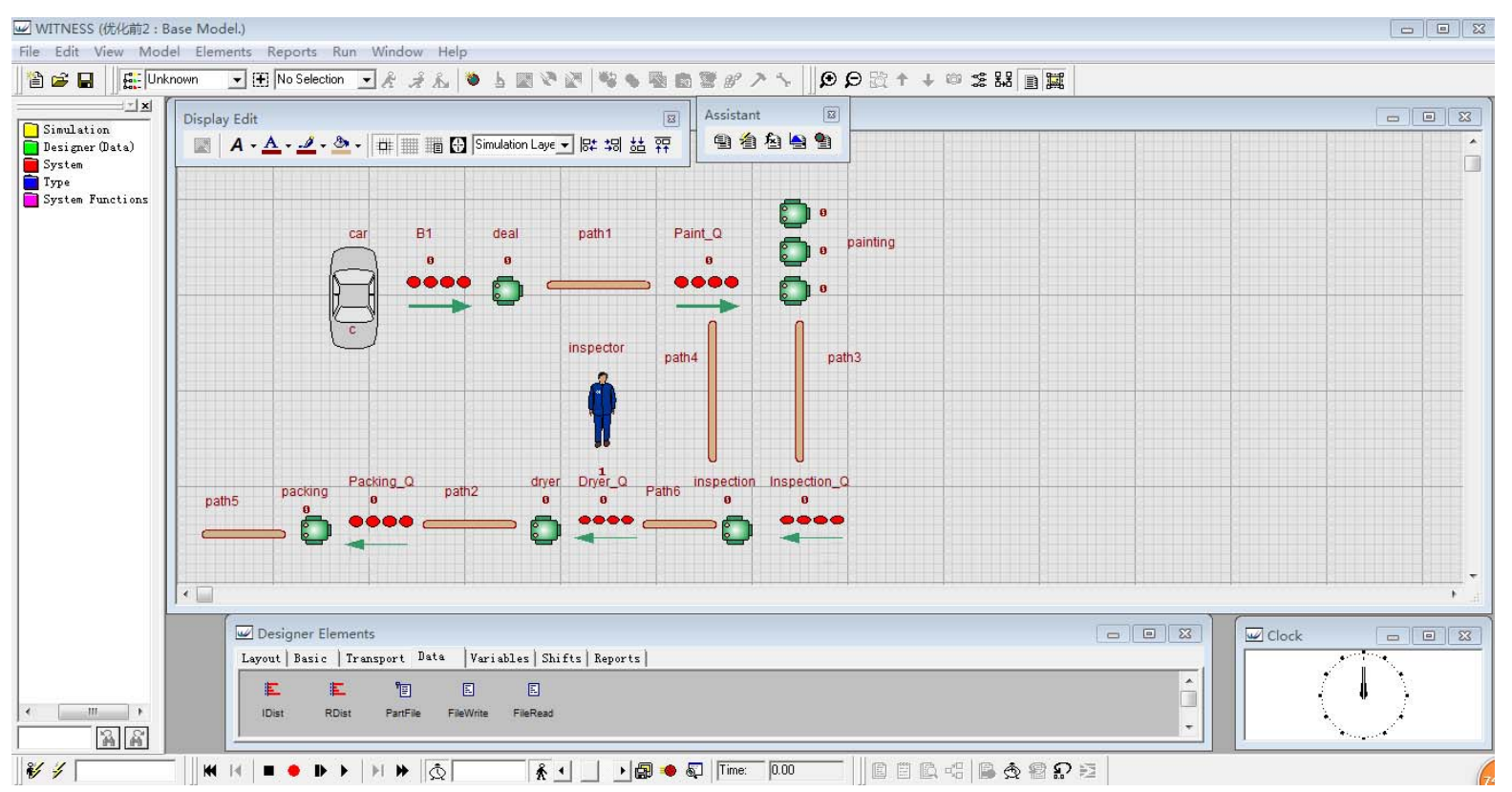

Fig.8 Witness simulation model after optimization

4.2 Analysis and comparison of the simulation result after optimization.

Still set the working time 200min, simulation results shown in Figure9 and 10.

We WITNESS
Machine Statistics
\begin{tabular}{|c|r|r|r|r|r|r|r|r|r|r|r|}
\hline Name & $\begin{array}{c}\% \\
\text { Idle }\end{array}$ & $\begin{array}{c}\% \\
\text { Busy }\end{array}$ & $\begin{array}{c}\% \\
\text { Filling }\end{array}$ & $\begin{array}{c}\% \\
\text { Emptying }\end{array}$ & $\begin{array}{c}\% \\
\text { Blocked }\end{array}$ & $\begin{array}{c}\text { \% Cycle } \\
\text { Wait Labor }\end{array}$ & $\begin{array}{c}\% \\
\text { Setup }\end{array}$ & $\begin{array}{c}\text { \% Setup } \\
\text { Wait Labor }\end{array}$ & $\begin{array}{c}\% \\
\text { Broken }\end{array}$ & $\begin{array}{c}\% \text { Repair } \\
\text { Wait }\end{array}$ & $\begin{array}{c}\text { No. Of } \\
\text { Operation }\end{array}$ \\
\hline deal & 0.00 & 100.00 & 0.00 & 0.00 & 0.00 & 0.00 & 0.00 & 0.00 & 0.00 & 0.00 & 66 \\
\hline painting(1) & 1.50 & 98.50 & 0.00 & 0.00 & 0.00 & 0.00 & 0.00 & 0.00 & 0.00 & 0.00 & 19 \\
\hline painting(2) & 3.00 & 97.00 & 0.00 & 0.00 & 0.00 & 0.00 & 0.00 & 0.00 & 0.00 & 0.00 & 19 \\
\hline painting(3) & 4.50 & 95.50 & 0.00 & 0.00 & 0.00 & 0.00 & 0.00 & 0.00 & 0.00 & 0.00 & 19 \\
\hline dryer & 31.00 & 29.00 & 0.00 & 0.00 & 0.00 & 40.00 & 0.00 & 0.00 & 0.00 & 0.00 & 29 \\
\hline packing & 88.00 & 12.00 & 0.00 & 0.00 & 0.00 & 0.00 & 0.00 & 0.00 & 0.00 & 0.00 & 6 \\
\hline inspection & 14.00 & 37.81 & 0.00 & 0.00 & 10.13 & 38.06 & 0.00 & 0.00 & 0.00 & 0.00 & 37 \\
\hline
\end{tabular}

Fig.9 machine working status statistics

Idle time of drying and inspection is $31 \%$ and $14 \%$ respectively and before optimization is $83 \%$ and $65.64 \%$, operating efficiency improved significantly.

Purt Statistics Report by On Shift Time
\begin{tabular}{|c|r|r|r|r|r|r|c|c|r|}
\hline Part & No. \\
Name & $\begin{array}{c}\text { No. } \\
\text { Entered }\end{array}$ & $\begin{array}{c}\text { No. } \\
\text { Shippe }\end{array}$ & $\begin{array}{c}\text { No. } \\
\text { Scrapped }\end{array}$ & $\begin{array}{c}\text { No. } \\
\text { Assemble }\end{array}$ & $\begin{array}{c}\text { No. } \\
\text { Rejected }\end{array}$ & $\begin{array}{l}\text { W.I.P } \\
\text {. }\end{array}$ & $\begin{array}{c}\text { Avg } \\
\text { W.I.P. }\end{array}$ & $\begin{array}{c}\text { Avg } \\
\text { Time }\end{array}$ & Sigma Rating \\
\hline car & 101 & 0 & 0 & 18 & 0 & 83 & 44.69 & 88.50 & 6.00 \\
\hline
\end{tabular}

Fig.10 Body working status statistics after optimization

Average time of body painting reduce from $100 \mathrm{~min}$ to $88.5 \mathrm{~min}$.

Through comparative analysis shows wait time and total production time are shortened, the number of production also increase, improve production efficiency significantly.

\section{Conclusion}

Automotive logistics play a pivotal role in the production process, the production efficiency of car can be boosted by improving the efficiency of logistics. Automobile production with high automation require a higher synchronization degree, but the painting owning poor efficiency which as a key link affect the overall workpiece ratio through research and analysis of early stage for the production site. The painting process include pre-treatment, coating, inspection, drying, staging and other five stations, according to the current job situation of each station, the application of Witness in modeling and simulation, the running result reveal that the coating station is the bottleneck because of the station has only one line and sometimes need to spray a variety of colors, two coating lines are added to solve the problem that waiting too long and moving back and forth, a new model used Witness is established and the result show that the production line running blocking has been obviously improved, the average time of painting processes reduce from 100 to 88.5 minutes, 
drying and inspection time decline, the car's the monthly output increased from 1000 to 1250 units, improving the overall efficiency of the production achieve the desired objective.

\section{References}

[1] Zhang Yingli, Shao Ming Xi. Modeling and simulation of production logistics system in enterprises [J], Logistics Technology, (2005) No.11, p.62-66

[2] Li Minghe, Lu Weifeng. modeling and simulation of material transportation system for workshop based on Petri net [J],J.of Anhui University of Technology, (2004)No.1,p. 45-48

[3] Zheng shunshui, Study on Techniques Simulation of Production System [J] O. I. Automation: (2004) No.4, p. 22-24

[4] Tung Chee-hwa, Xiao Tian Yuan, Fan Shuhai, Planning Strategy and Simulation Environment of Automotive Assembly Lines for Mass Customization [J], Journal of System Simulation, (2003)No.2,p.202-205

[5] Wang Ya-chao, Ma Hanwu, Production logistics system modeling and simulation -Witness system and application [M] Beijing: Science Press, 2006.

[6] Chai Furong, Wang Hongun, simulation and optimization of production rhythm of camshaft production line based on Witness [J] Manufacturing Automation, (2014)No.9,p. 39-42

[7] Tang Yi, Zhou Binghai, production line planning and evaluation based on Witness simulation [J] Modular Machine Tool \& Automatic Manufacturing Technique, (2009) No.7, p. 5-8

[8] Yunrui Wang, Inventory System Simulation Based on Witness[J], Journal of Applied Science and Engineering Innovation, (2014)No.3, p. 208-211

[9] Mao Jian, Qiao Jinyou, Wang Lijun, Wang Ying. Witness Simulation of production logistics system based on auto parts [J] Industrial Engineering, (2011) No.3, p. 124-127

[10] Shi Yuqiang, Research on optimization of production line by double-e and Flexsim [J]. Mechanical design and manufacturing, (2011) No.2, p. 130-131 